\title{
2
}

Stanisław Goźdź-Roszkowski, Jacek Makowski

Uniwersytet Łódzki

http://dx.doi.org/10.18778/8088-905-7.03

\section{Jak twórczo kształcić humanistów dla potrzeb rynku pracy? Studium przypadku: kierunek lingwistyka dla biznesu na Uniwersytecie Łódzkim}

\section{Wstęp}

Celem niniejszych rozważań jest podzielenie się doświadczeniami oraz refleksją nad koncepcją i wdrażaniem nowego kierunku studiów uniwersyteckich o nazwie lingwistyka dla biznesu.

Inicjatywa powołania takiego kierunku powstała na Wydziale Filologicznym jako próba realizacji tzw. "trzeciej misji” uczelni wyższej, obejmującej współpracę z szeroko rozumianym otoczeniem społeczno-gospodarczym, a więc z sektorem przedsiębiorstw, sektorem publicznym oraz pozarządowym. Podjęcie prac nad programem studiów stanowiło konsekwencję systematycznego pogłębiania współpracy między Wydziałem Filologicznym a przedsiębiorcami i pracodawcami, mającej na celu współtworzenie programów dydaktycznych, prowadzenie wspólnych zajęć i warsztatów, organizowanie staży, zgłaszanie problemów badawczych do opracowania $\mathrm{w}$ ramach prac dyplo- 
mowych, jak również współtworzenia innowacyjnych, nowych kierunków studiów będących odpowiedzią na aktualne potrzeby rynku pracy. Wszystkie te elementy zostały wykorzystane w ramach tworzenia nowego kierunku i ich omówienie stanowi treść niniejszego rozdziału. Poza nowatorskim łączeniem przedmiotów z zakresu nauk humanistycznych z naukami z obszaru zarządzania i kształceniem dwóch języków obcych, stworzenie nowego programu studiów ma wydatnie zwiększyć szanse absolwentów na znalezienie zatrudnienia zarówno w krótkoterminowej, jak i długoterminowej perspektywie. Innymi słowy, twórcy nowego kierunku za kluczowe przyjęli założenie o konieczności stworzenia podstaw trwałej zatrudnialności absolwentów lingwistyki dla biznesu.

\section{Współtworzenie programu studiów}

Od samego początku projekt edukacyjny lingwistyka dla biznesu postrzegany był jako przedsięwzięcie wymagające współpracy różnych jednostek i środowisk. Mając na uwadze aktualne trendy w zakresie badań filologicznych nad aspektem nauczania języków obcych na poziomie akademickim, uwzględniającego potrzeby rynku pracy, trzeba się zgodzić z autorami publikacji Nauczanie języków obcych na potrzeby rynku pracy (Sowa $\mathrm{i}$ in. 2015), że kształcenie takie nie jest wyłącznie sprawą samych placówek edukacyjnych. Szkoły wyższe muszą ściśle współpracować z różnymi partnerami, aby pełniej sprostać wymaganiom pozaszkolnej rzeczywistości zawodowej (por. Sowa i in. 2015: 9-10). Wśród partnerów powinni się znaleźć, jak słusznie zauważają autorzy, "tak sami uczący się, jak i przyszli pracodawcy”, zaś wynikiem owej współpracy powinny być „innowacyjne i/lub «szyte na miarę» czasów oraz potrzeb rozwiązania dydaktyczne w postaci programów, metod, narzędzi czy technik nauczania" (Sowa i in. 2015: 10). Pierwotna koncepcja studiów opracowywana była przez zespół składający się z filologów reprezentujących różne języki i specjalności: germanistów, anglistów, ro- 
manistów, italianistów i rusycystów. Dość szybko okazało się, że niezbędne jest wyjście poza sferę czysto filologiczną i zaproszenie do współpracy specjalistów z Wydziału Zarządzania. Stało się to możliwe dzięki życzliwości i zrozumieniu ówczesnej dziekan Wydziału Zarządzania prof. dr hab. Ewy Walińskiej. $\mathrm{W}$ rezultacie koncepcja programowa zorientowana lingwistycznie została uzupełniona i rozszerzona o paletę zajęć o charakterze ekonomicznym. Warto podkreślić, że program tworzono od podstaw, bez możliwości odniesienia się do istniejących wzorców. Jednym z zasadniczych problemów była konieczność zintegrowania dwóch różnych dyscyplin w ramach jednego spójnego programu przeznaczonego dla studentów o predyspozycjach raczej humanistycznych. Kierunek został uruchomiony w 2013 r. w wyniku ścisłej współpracy między Wydziałem Filologicznym oraz Wydziałem Zarządzania, do której zaproszono również dwie firmy z branży, działające na terenie Łodzi: Hewlett Packard oraz Infosys. Od roku 2015 partnerem programu jest również firma Fujitsu. Udział partnerów biznesowych w projekcie edukacyjnym polegał na konsultowaniu treści nauczania, włączeniu warsztatów biznesowych prowadzonych przez przedstawicieli firm do programu studiów oraz organizacji praktyk zawodowych dla studentów. Wybór partnerów biznesowych był $\mathrm{w}$ znacznej mierze podyktowany analizą lokalnego rynku. W regionie łódzkim kluczową rolę odgrywają firmy sektora BPO, czyli centra świadczące nowoczesne usługi dla biznesu. Firmy działające $\mathrm{w}$ tej branży są zorientowane na klientów zewnętrznych - przejmują od nich realizację procesów, w szczególności usług z zakresu technologii komunikacyjnych i informacyjnych (37\%), finansów i rachunkowości (19\%), bankowości, usług finansowych i ubezpieczeń (BFSI) (11\%) oraz szeroko rozumianej obsługi klienta (customer operations) $(10 \%)$ (szczegółowe dane por. Górecki i in. 2016: 28). Jednym z najistotniejszych problemów, przed jakim stanęli twórcy kierunku, było opracowanie programu nauczania, łączącego przygotowanie absolwentów do pracy w sektorze usług dla biznesu z perspektywami zatrudnienia poza rzeczonym segmentem rynku. Uważamy, że stało się to możliwe dzięki unikalnemu połączeniu kształcenia obejmują- 
cego wiedzę językoznawcza, zarządzanie (problematykę bizne$\mathrm{su}$ ), praktyczne umiejętności biznesowe $\mathrm{z}$ wysokim poziomem kompetencji w zakresie dwóch języków obcych, w tym języków specjalistycznych.

\section{Podstawowe założenia i charakterystyka programu studiów}

W tej sekcji pragniemy zwięźle przedstawić wyniki prac nad ułożeniem oryginalnego programu studiów, w którym staraliśmy się pogodzić interesy wszystkich podmiotów współtworzących kierunek ${ }^{1}$. Ogólna struktura programu przedstawiona jest $\mathrm{w}$ tab. 2.1. Przedmioty prowadzone $\mathrm{w}$ ramach lingwistyki można pogrupować w pięciu głównych kategoriach: przedmioty językoznawcze, przedmioty z zakresu zarządzania, język angielski, inne języki obce oraz warsztaty biznesowe.

Przedmioty językoznawcze mają dostarczyć studentom niezbędnej wiedzy z zakresu językoznawstwa stosowanego, ukierunkowanego na problematykę komunikacji w kontekstach kulturowych i specjalistycznych. Interkulturowość i kulturowa specyfika są wpisane $\mathrm{w}$ istotę prezentowanego kierunku studiów, zwłaszcza w świetle działalności głównych partnerów biznesowych (firmy Infosys oraz HP), nastawionych na świadczenie usług (np. w zakresie księgowości) dla klientów z całego świata.

Kolejna kategoria to przedmioty $\mathrm{z}$ obszaru zarządzania, umożliwiające kształcenie praktycznych umiejętności z zakresie prowadzenia biznesu. Podział na kategorie jezzyk angielski i inne języki obce wynika z przyjętej zasady dwujęzyczności. Program studiów przewiduje nauczanie dwóch języków obcych, tj. języka angielskiego oraz drugiego języka obcego w ramach opcji przewidzianej dla danego rocznika, która co roku podlega modyfikacji. Na przykład w roku akademickim 2013/2014, w pierwszym roku

1 Szczegółowy opis programu studiów z uwzględnieniem roli języków specjalistycznych można znaleźć w: Goźdź-Roszkowski, Makowski (2015). 
Tabela 2.1. Ogólna struktura programu studiów lingwistyka dla biznesu

\begin{tabular}{|l|}
\hline Przedmioty językoznawcze \\
\hline Nauka o komunikacji \\
Podstawy lingwistyki stosowanej \\
Języki specjalistyczne: wstęp \\
Pragmatyka językowa \\
Komunikacja interkulturowa \\
\hline Przedmioty z zakresu zarządzania \\
\hline Język angielski \\
\hline Praktyczna nauka języka angielskiego \\
Business English \\
Międzynarodowy język prawa \\
\hline Języki obce \\
\hline Praktyczna nauka języka (np. niemieckiego) \\
Języki specjalistyczne (finansów, HR, logistyki) \\
Kultura współczesna kraju \\
Tłumaczenia specjalistyczne \\
\hline Warsztaty biznesowe i praktyki zawodowe \\
\hline
\end{tabular}

Źródło: opracowanie własne

funkcjonowania kierunku, studenci mogli wybrać język niemiecki, francuski lub włoski. W ramach rekrutacji na rok 2016/2017, poza niemieckim i francuskim, studenci mają również do wyboru język chorwacki. Oferta drugiego języka jest, z jednej strony, podyktowana możliwościami wydziału, z drugiej zaś - analizą zapotrzebowania na języki obce, które jest zgłaszane przez pracodawców. Istotne jest również stworzenie możliwości kształcenia w zakresie języków mniej znanych, niszowych, których znajomość może zwiększyć atrakcyjność absolwenta w oczach potencjalnego pracodawcy. Język angielski ma inny status niż pozostałe języki obce, zwłaszcza w komunikacji korporacyjnej, w której stanowi podstawowe narzędzie porozumiewania się. Z tego względu przyjęliśmy założenie, że studenci rozpoczynający studia powinni posiadać znajomość tego języka przynajmniej na poziomie B1, a kończący - na poziomie B2. Zajęcia z języka angielskiego mają więc na celu utrzy- 
manie i niewielki wzrost ogólnych kompetencji językowych. Nacisk jest położony na nauczanie języków specjalistycznych - Business English oraz języka prawa w zakresie prawa spółek, zobowiązań itd. Inaczej wygląda kwestia nauczania drugiego języka obcego, którego studenci zaczynają się uczyć na poziomie niższym niż w przypadku języka angielskiego (np. wybierający język chorwacki uczą się go od podstaw). Celem kształcenia jest uzyskanie kompetencji językowej na poziomie B2/C1 zgodnie z normami Europejskiego Systemu Opisu Kształcenia Językowego (ESOKJ)². Nauczanie drugiego języka obcego również zakłada kształcenie umiejętności w ramach tzw. języka specjalistycznego lub fachowego. Studenci poznają język HR i finansów, logistyki oraz język nowych technologii (IT).

\section{Prowadzenie wspólnych zajęć i warsztatów. Praktyki zawodowe}

Integralną częścią programu studiów są warsztaty biznesowe prowadzone w semestrze II oraz IV przez przedstawicieli partnerów biznesowych, a więc firm Infosys, Hewlett Packard i Fujitsu. Zakres zajęć w języku angielskim wyznacza program ustalany przez firmy, dotyczą one praktycznych aspektów funkcjonowania przedsiębiorstwa. Kończy je test na zaliczenie. Studenci są również zobowiązani do odbycia praktyk zawodowych w liczbie 450 godzin. Praktyki mają miejsce we współpracujących z uczelnią firmach lub w innych, wybranych przez studenta przedsiębiorstwach, po uprzednim uzyskaniu zgody opiekuna praktyk. Mogą być realizowane w okresie letnim lub w trakcie piątego semestru studiów. Zajęcia przybierają wtedy formę studiów dualnych. Studenci spędzają na uczelni dwa dni w tygodniu, w pozostałe dni mogą przebywać na praktykach w firmach.

${ }^{2}$ Dla języka angielskiego zakładane jest osiągnięcie poziomu B2+, zaś dla drugiego języka obcego poziom C1. 


\section{Projekty w ramach prac dyplomowych}

Jako szczególnie twórczy aspekt omawianego kierunku studiów na Uniwersytecie Łódzkim można zaliczyć zaplanowane na piąty i szósty semestr zajęcia $\mathrm{w}$ ramach seminarium dyplomowego oraz opracowanie pracy dyplomowej. Z uwagi na praktyczny i zawodowy charakter kierunku przyjęliśmy zasadę, że prace licencjackie tworzone są $\mathrm{w}$ formie projektów, realizowanych w 3- i 4-osobowych zespołach projektowych. Prowadzący seminarium orientują studentów odnośnie różnych aspektów komunikacji zawodowej. Tematyka projektów licencjackich pierwszej edycji kierunku, zakończona w egzaminacyjnej sesji letniej 2015/2016, była ściśle związana z interdyscyplinarnym i praktycznym charakterem kierunku studiów i obejmowała m.in. analizy możliwości zawodowych absolwentów kierunku L4B, język reklamy i kampanii społecznych, aspekt społecznej odpowiedzialności biznesu (CSR), komunikację wewnętrzną i zewnętrzną międzynarodowych korporacji i przedsiębiorstw oraz grup projektowych (na przykładzie metodologii Kobetsu Kaizen), komunikację $\mathrm{w}$ mediach społecznościowych i $\mathrm{w}$ internecie, technologię chmury obliczeniowej (cloud computing) i związanej z tym zagadnieniem wiedzy fachowej oraz terminologii. Ponadto $w$ ramach projektów dyplomowych poruszano także aspekty tekstologiczne (gatunki i rodzaje tekstów w komunikacji biznesowej i zarządzaniu zasobami ludzkimi), zagadnienia socjolingwistyczne (np. „korpo-mowa” jako profesjolekt, charakterystyka żargonów zawodowych), leksykologiczne oraz przekładoznawcze (tłumaczenia audiowizualne $\mathrm{w}$ aspekcie kulturowym). Jako rezultaty projektu opracowane zostały bardzo wartościowe i praktyczne - naszym zdaniem znacznie wykraczające poza dość konwencjonalny, odtwórczy charakter przeważającej liczby prac licencjackich - narzędzia, opracowania, analizy, glosariusze, słowniki, poradniki, wzory tekstów (tzw. templatki) oraz filmy instruktażowe, które z powodzeniem mogą zostać wdrożone i wykorzystane zarówno przez pracodawców, jak i przez studentów oraz uczelnię. 


\section{Rynek pracy i otoczenie społeczno- -gospodarcze w wymiarze lokalnym i krajowym - perspektywy na przyszłość}

W ostatnich latach sektor tzw. nowoczesnych usług dla biznesu stał się branżą odnotowującą niezwykle dynamiczny rozwój. W roku 2007 funkcjonowało już ponad 200 centrów usług z kapitałem zagranicznym (w porównaniu z 91 centrami działającymi w 2004, blisko 300 centrami w 2010, ponad 400 w 2012 i $470 \mathrm{w}$ roku 2014). Obecnie, według najnowszych danych, w Polsce działa już ponad 590 firm-inwestorów, posiadających swoje centra usług (w tym 461 inwestorów zagranicznych), a całkowita liczba centrów usług w skali kraju to 936, w tym 676 centrów zagranicznych (stan na kwiecień 2016, por. Górecki i in. 2016: 7). Już w 7 ośrodkach usług biznesowych w Polsce zatrudnienie przekroczyło 10 tys. osób, zaś wzrost zatrudnienia w centrach zagranicznych od kwietnia 2015 r. do kwietnia 2016 r. wyniósł $25 \%$ i był większy niż w poprzednich latach. W najnowszym raporcie Związku Liderów Sektora Usług Biznesowych (Górecki $i$ in. 2016) poddaje się rewizji dotychczasowe prognozy dotyczące zatrudnienia w wymienionym. sektorze, ponieważ w miejsce prognozowanych w 2015 r. (por. Górecki 2015) 220 tys. zatrudnionych zatrudnienie w sektorze w roku 2020 szacuje się na poziomie 300 tys. osób. Łódź znajduje się obecnie w gronie sześciu największych ośrodków usług dla biznesu w Polsce (15 600 zatrudnionych), ustępując miejsca takim ośrodkom, jak: Kraków (50 300 stanowisk), Warszawa (36 700), Wrocław (34 200), Trójmiasto (16 900) oraz Aglomeracja Katowicka (16 500) (por. Górecki i in. 2016: 12). Porównanie danych z ostatnich trzech lat, dotyczących zatrudnienia w Łodzi w sektorze usług dla biznesu świadczy o znaczącym wzroście: 10800 zatrudnionych w 2014 r., 13100 w 2015 r. i 15600 stanowisk w 2016 (por. Górecki i in. 2014, 2015), co na przestrzeni trzech lat daje przyrost zatrudnienia rzędu 4800 zatrudnionych. Przeprowadzona w 2015 r. analiza danych dotyczących zapotrzebowania sektora nowoczesnych usług biznesowych na kandydatów ze znajomością języków 
obcych pozwoliła wyizolować najbardziej kluczowe tendencje dotyczące zastosowania języków obcych w sektorze nowoczesnych usług biznesowych w Łodzi, które można skupić wokół następujących obszarów:

1. Jako wyraźny trend w zakresie znajomości języków obcych odznacza się wielojęzyczność według schematu ,,język angielski jako wewnętrzny język korporacji (poziom kompetencji min. B1/B2) plus drugi jezzyk obcy (J2) jako język roboczy (poziom kompetencji C1-C2)". Język angielski wraz z drugim językiem obcym - niemieckim - to zaś najczęściej używana kombinacja, a na kolejnych miejscach jako J2 znajdują się: języki francuski, hiszpański, niderlandzki, turecki i włoski. Najbardziej poszukiwanymi językami obcymi są język niemiecki, angielski i węgierski, respondenci zgłaszają ponadto zapotrzebowania na języki niszowe, jak przykładowo języki skandynawskie. Pracodawcy podkreślają ponadto znaczenie wszystkich sprawności językowych, z wyraźnym wskazaniem na komunikację z klientem (telefonicznie i/lub za pośrednictwem poczty elektronicznej) oraz recepcję i tworzenie tekstów użytkowych, a także tłumaczenia pisemne oraz ustne (ze wskazaniem na wykorzystanie kompetencji tłumaczeniowej na potrzeby wewnętrzne przedsiębiorstwa, jak np. tłumaczenia tekstów fachowych do wewnętrznego wykorzystania w ramach firmy, tłumaczenia ustne spotkań zespołów, briefingów itp.). Respondenci podkreślają umiejętność szybkiego uczenia się oraz kompetencje miękkie. Szkolenia językowe prowadzone są we wszystkich zbadanych przedsiębiorstwach, zarówno przez podmioty zewnętrzne, jak i przez wewnętrznych trenerów.

2. Jako najczęściej używane przez respondentów języki specjalistyczne należy wskazać języki następujących dziedzin: księgowości i finansów, bankowości, zarządzania zasobami ludzkimi (HR), IT oraz szeroko rozumiany język biznesu, w tym także Business English. Deklarowane gatunki tekstów używane w ramach komunikacji specjalistycznej w części są pochodną deklarowanych języków specjalistycznych, wynikających z obsługiwanych przez centra procesów. Respondenci wymieniali takie teksty specjalistyczne, jak faktura, wyciag bankowy, formularz 
bankowy, nota kredytowa (księgowość, finanse i bankowość), ogłoszenie rekrutacyjne, list motywacyjny (HR), artykuły do knowledge base, dokumentacja techniczna (IT), zapytanie ofertowe, reklamacja oraz odpowiedź na nia, e-mail, zamówienie, zlecenie, list dostawy (szeroko rozumiany język biznesu i komunikacja biznesowa). Do najczęściej używanych gatunków tekstów należy zaliczyć fakturę, zapytanie ofertowe, reklamację oraz e-mail (całość wyników por. Makowski 2015, zobacz także Bednarek 2015).

\section{Podsumowanie}

Niniejszy artykuł miał na celu ukazanie przykładu współpracy uczelni wyższej z pracodawcami przy tworzeniu zupełnie nowego kierunku studiów. Jej efektem jest przygotowanie przyszłych pracowników odpowiadających na zapotrzebowanie rynku pracy oraz wspólne tworzenie nowych kierunków studiów, programów kształcenia, sylabusów zajęć dydaktycznych prowadzonych przez pracowników uniwersyteckich, a także przedstawicieli lub pracowników firm działających na rynku pracy. Tak przygotowane zajęcia i warsztaty gwarantują teoretyczne i praktyczne przygotowanie studentów - przyszłych pracowników do podjęcia wyzwań podczas staży, praktyk lub w przyszłych docelowych miejscach pracy. Zajęcia przygotowane wspólnie przez środowisko uniwersyteckie i gospodarcze pozwalają również na poszerzenie możliwości kształtowania pola badawczego poprzez formułowanie tematów prac magisterskich, tematów wystąpień lub artykułów. Docelowo praca badawcza studentów może owocować rozwiązaniem rzeczywistych problemów występujących na rynku pracy. Mając na uwadze dynamikę rynku $\mathrm{BPO}$, trzeba stwierdzić, że kierunek lingwistyka dla biznesu jest przyszłościowy i rozwojowy, wymaga jednocześnie „twórczego" podejścia - ewaluacji potrzeb i ewentualnej reakcji na zapotrzebowanie rynku. 


\section{Literatura}

Bednarek A. (2015), Zapotrzebowanie firm z sektora nowoczesnych usług biznesowych w zakresie kandydatów ze znajomościa języków obcych, publikacja w ramach projektu "Lingwistyka dla ekoodpowiedzialnego biznesu MA", FSS/2014/HEI/W/0110, Uniwersytet Łódzki, www.14bma.uni.lodz.pl [dostęp: 1.07.2016].

Górecki J., Dzierań A., Kapusta E., Karpiesiuk Ł., Polkowski M., Raychaudhuri Sh., Srivastava A. (2015), Sektor nowoczesnych ustug biznesowych w Polsce 2015, Związek Liderów Sektora Usług Biznesowych, www.absl.pl/pl/web/guest/absl-publications [dostęp: 1.07.2016].

Górecki J., Gurszyńska K., Karpiesiuk Ł., Polkowski M. (2016), Sektor nowoczesnych usług biznesowych w Polsce 2016, Związek Liderów Sektora Usług Biznesowych, www.absl.pl/pl/web/guest/absl-publications [dostęp: 1.07.2016].

Górecki J., Jamioł J., Jasińska M., Karpiesiuk Ł., Klecha A., Micek G., Polkowski M. (2014), Sektor nowoczesnych ustug biznesowych w Polsce 2014, Związek Liderów Sektora Usług Biznesowych, www.absl.pl/pl/web/guest/absl-publications [dostęp: 1.07.2016].

Goźdź-Roszkowski S., Makowski J. (2015), „Lingwistyka dla biznesu czy biznes dla lingwistyki?" - rola i miejsce specjalistycznych języków obcych w programie interdyscyplinarnych studiów uniwersyteckich, [w:] M. Sowa, M. Mocarz-Kleindienst, U. Czyżewska, Nauczanie języków obcych na potrzeby rynku pracy, Wydawnictwo Katolickiego Uniwersytetu Lubelskiego im. Jana Pawła II, Lublin, s. 67-78.

Makowski J. (2015), Ewaluacja potrzeb przedsiębiorstw w zakresie kandydatów ze znajomościa języków obcych. Wyniki badania ankietowego, publikacja w ramach projektu "Lingwistyka dla ekoodpowiedzialnego biznesu MA", FSS/2014/HEI/W/0110, Uniwersytet Łódzki, www.14bma.uni.lodz.pl [dostęp: 1.07.2016].

Sowa M., Mocarz-Kleindienst M., Czyżewska U. (2015), Nauczanie języków obcych na potrzeby rynku pracy, Wydawnictwo Katolickiego Uniwersytetu Lubelskiego im. Jana Pawła II, Lublin. 